\title{
Aktivitas Antibakteri dari Jamur Endofit Penicillium oxalicum Hasil Isolasi dari Spons Homaxinella tanitai
}

Ni Putu Diah Parwita Sari ${ }^{1}$, Bian Dwi Cahyo ${ }^{2}$, Noor Erma Nasution Sugijanto ${ }^{3}$, Suciati $^{3 *}$

${ }^{1}$ Program Studi Pendidikan Apoteker, Fakultas Farmasi, Universitas Airlangga, Surabaya, Indonesia

${ }^{2}$ Rumah Sakit Angkatan Laut Jala Ammari, Makassar, Indonesia

${ }^{3}$ Departemen Ilmu Kefarmasian, Fakultas Farmasi, Universitas Airlangga, Surabaya, Indonesia

*Corresponding author: suciati@ff.unair.ac.id

Submitted: 11 Maret 2020

Accepted: 19 Juni 2020

Published: 27 April 2021

\begin{abstract}
Background: Marine-derived fungi have been known as the source of many fascinating metabolites with promising bioactivities, including antibacterial activity. Objective: The aim of this study was to investigate the antibacterial activity of the ethyl acetate extract and its fractions of an endophytic fungus isolated from a marine sponge Homaxinella tanitai fungus against Gram positive bacterias Staphylococcus aureus and Bacillus subtilis, as well as Gram negative bacteria Eschericia coli. Methods: Identification of the endophytic fungus was carried out based on $28 S$ rRNA sequences. The fungus was grown in malt extract medium made with artificial sea water. Extraction was carried by liquid-liquid partition with ethyl acetate. Fractionation was carried out by flash chromatography. The antibacterial assay was conducted using both microdillution and disk diffusion assays. Phytochemical screening of the extract was carried out by TLC visualized with dyeing reagents as well as ${ }^{1} H$ NMR spectroscopy. Results: Based on 28S rRNA, the fungus was identified as Penicillium oxalicum strain FEC-128. The ethyl acetate extract of P. oxalicum showed antibacterial activity against B. subtilis and E. coli with MIC value of $250 \mu \mathrm{g} / \mathrm{mL}$, and against $S$. aureus with MIC value of $500 \mu \mathrm{g} / \mathrm{mL}$. Flash chromatography fractions of the extract at concentration $100 \mu \mathrm{g} /$ disk showed moderate inhibition against three tested bacterias. Based on TLC and ${ }^{1} H$ NMR data the ethyl acetate extract contains terpenoid and polifenol. Conclusion: The endophytic fungus P. oxalicum isolated from the marine sponge H. tanitai showed antibacterial activities against Gram positive and Gram negative bacterias.
\end{abstract}

Keywords: Penicillium oxalicum, endophytic fungus, antibacterial activity, marine sponge, Homaxinella tanitai

\begin{abstract}
Abstrak
Pendahuluan: Jamur endofit yang berasal dari biota laut spons diketahui sebagai sumber penghasil berbagai jenis metabolit sekunder. Metabolit sekunder yang dihasilkan telah dilaporkan memiliki beberapa bioaktivitas termasuk sebagai antibakteri. Tujuan: Penelitian ini bertujuan untuk mengetahui aktivitas antibakteri dari ekstrak etil asetat dan fraksi dari jamur endofit Penicillium oxalicum yang diisolasi dari spons Homaxinella tanitai terhadap bakteri Gram positif Staphyloccus aureus dan Bacillus subtilis serta bakteri Gram negatif Eschericia coli. Metode: Identifikasi jamur endofit dilakukan berdasarkan sekuensing dari $28 \mathrm{~S}$ rRNA. Jamur endofit $P$. oxalicum ditumbuhkan pada media malt extract. Ekstraksi dilakukan dengan metode partisi cair-cair dengan pelarut etil asetat. Fraksinasi dari ekstrak etil asetat dilakukan dengan metode kromatografi kolom cepat. Uji aktivitas antibakteri dari ekstrak dan fraksi dilakukan dengan metode mikrodilusi dan difusi agar. Skrining golongan senyawa pada ekstrak dilakukan dengan metode KLT yang divisualisasi dengan berbagai penampak noda serta menggunakan spektroskopi ${ }^{1} \mathrm{H}$ NMR. Hasil: Hasil yang diperoleh menunjukkan bahwa ekstrak etil asetat $P$. oxalicum memberikan aktivitas antibakteri terhadap $B$. subtilis dan $E$. coli dengan konsentrasi hambat minimum (KHM) $250 \mu \mathrm{g} / \mathrm{mL}$ dan menghambat pertumbuhan S. aureus dengan KHM $500 \mu \mathrm{g} / \mathrm{mL}$. Hasil uji aktivitas antibakteri dari fraksi pada konsentrasi $100 \mu \mathrm{g} / \mathrm{cakram}$ menunjukkan aktifitas penghambatan yang sedang terhadap ketiga bakteri uji. Berdasarkan hasil KLT dan spektroskopi ${ }^{1} \mathrm{H}$ NMR, dapat diketahui bahwa ekstrak etil asetat $P$.
\end{abstract}


oxalicum mengandung senyawa terpenoid dan polifenol. Kesimpulan: Jamur endofit $P$. oxalicum yang diisolasi dari spons $H$. tanitai menunjukkan aktivitas antibakteri terhadap bakteri Gram positif dan Gram negatif.

Kata kunci: Penicillium oxalicum, jamur endofit, antibakteri, spons, Homaxinella tanitai

\section{PENDAHULUAN}

Penyakit infeksi adalah penyakit yang terjadi akibat keberadaan dan pertumbuhan agen biologis patogenik pada organisme host individu. Patogen penginfeksi meliputi bakteri, jamur, virus, protozoa, dan parasit. Penyakit infeksi di Indonesia masih termasuk ke dalam sepuluh penyakit terbanyak (Kemenkes RI, 2019). Upaya pengobatan terhadap penyakit infeksi telah banyak dilakukan, penanganan yang umumnya digunakan adalah penggunaan antimikroba. Tetapi, penggunaan antimikroba secara tidak rasional baik dalam dosis maupun jangka waktu penggunaan dapat memicu terjadinya resistensi terhadap antimikroba sehingga menyebabkan terjadinya morbiditas dan mortalitas. Pada tahun 2014 dilaporkan angka kematian akibat resistensi antimikroba adalah 700.000 orang per tahun (Kemenkes RI, 2016). Dalam rangka mencari alternatif pengobatan penyakit infeksi, eksplorasi terhadap aktivitas antimikroba dari bahan alam baik dari tumbuhan, biota luat maupun mikroorganisme masih menjadi pilihan.

Spons merupakan salah satu biota laut yang dilaporkan menghasilkan berbagai senyawa bioaktif diantaranya sebagai antimikroba, antikanker, analgesik, antibakteri dan antijamur (Blunt dkk., 2018). Schmidt dkk., (2000) menyatakan kebanyakan bioaktivitas dari spons dapat berasal dari mikroorganisme yang berasosiasi dengannya, misalnya jamur dan bakteri endofit. Spons dari genus Homaxinella diketahui memiliki berbagai macam bioaktivitas, termasuk antimikroba. Umeyama dkk. (1998) telah mengisolasi senyawa alkaloid, longamide dari Homaxinella sp. Senyawa yang juga diisolasi dari spons Agelas longissima tersebut dilaporkan memiliki aktivitas antibakteri (Cafieri dkk., 1995).

Pada penelitian sebelumnya telah dilakukan isolasi tiga jamur endofit yang berasal dari spons genus Homaxinella yang diambil dari perairan Pulau Barrang Lompo, Makassar, Sulawesi Selatan. Ketiga jamur endofit tersebut diduga berasal dari kelas Deuteromycetes. Jamur endofit tersebut ditumbuhkan pada media padat malt extract agar dan diekstraksi dengan etanol 96\%. Hasil uji aktivitas antibakteri menunjukkan bahwa ekstrak etanol dari jamur endofit kode F17-5-14-3 memiliki aktivitas antibakteri terhadap
Staphyllococcus aureus (60 $\mu \mathrm{g} / \mathrm{cakram})$, Eschericia coli (120 $\mu \mathrm{g} / \mathrm{cakram})$ dan Vibrio cholerae (120 $\mu \mathrm{g} / \mathrm{cakram})$ (Suciati dkk., 2014). Pada penelitian ini dilakukan identifikasi jamur endofit F17-5-14-3, selanjutnya jamur ditumbuhkan pada media cair malt extract, dan dilakukan ekstraksi dengan pelarut etil asetat. Selanjutnya dilakukan fraksinasi terhadap ekstrak etil asetat tersebut dengan metode kromatografi kolom cepat. Uji aktivitas antibakteri dari ekstrak etil asetat dan hasil fraksinasinya dilakukan terhadap bakteri S. aureus, E. coli dan B. subtilis dengan metode mikrodilusi dan difusi agar.

\section{BAHAN DAN METODE}

\section{Bahan}

\section{Jamur endofit dan bakteri uji}

Jamur Endofit kode F17-5-14-3 diisolasi dari spons genus Homaxinella yang diambil dari perairan sekitar Pulau Barrang Lompo, Makassar, Sulawesi Selatan sesuai prosedur pada Suciati dkk, 2014. Bakteri uji yang digunakan adalah: Staphylococcus aureus ATCC 6538, Bacillus subtilis ATCC 6633 dan Eschericia coli ATCC 25922.

\section{Bahan kimia}

Media malt extract, nutrient broth, etil asetat p.a, air laut buatan, DMSO, $n$-heksana p.a, metanol p.a, MTT (3-(4,5-dimetiltiazol-2-il)-2-5-difenil tetrazolium bromid, siprofloksasin pharmaceutical grade.

Alat

Ultrasonik (Branson), rotary evaporator (Buchi), laminary air flow cabinet (LAFC) (Dalton), mikropipet (Soccorex), timbangan analitik (Alsep, Adventura OHAUS), autoklaf (Huxley HL-340 speedy), 96-well microtiter plate steril, kertas cakram steril, inkubator (Memmert), flash chromatography Sepacore ${ }^{\circledR}$ (Buchi), spektrofotometer (Bausch and Lomb).

\section{Metode}

\section{Identifikasi jamur endofit}

Identifikasi mikroba dilakukan di laboratorium penguji BP Bioteknologi BPPT Serpong. Metode yang digunakan adalah isolasi DNA, PCR, DNA sekuensing serta analisa sekuens dari ribosomal RNA pada daerah gen $28 \mathrm{~S}$ rRNA. Primer yang digunakan untuk memperbanyak daerah 28S rRNA adalah NL1 (5'- GCA TAT CAA TAA GCG GAG GAA AAG-3') dan NL4 
(5'- GGT CCG TGT TTC AAG ACG G-3'). Hasil sekuens dari ribosomal RNA kemudian dicocokkan dengan data pada GenBank (NCBI).

\section{Ekstraksi}

Jamur endofit $P$. oxalicum ditumbuhkan pada media malt extract (500 mL x 48 Erlenmeyer) yang dibuat dengan air laut buatan. Fermentasi dilakukan selama enam minggu pada suhu $22-25^{\circ} \mathrm{C}$. Pada akhir minggu keenam sebanyak 24 liter campuran media dan miselium jamur diekstraksi secara cair-cair dengan etil asetat. Ekstraksi dilakukan dengan menggunakan shaker selama 15 menit tiap ekstraksi, fase organik kemudian dipisahkan. Proses ekstraksi dilakukan 3 kali, kemudian filtrat dikumpulkan. Selanjutnya pelarut organik diuapkan dengan rotary evaporator pada suhu $40^{\circ} \mathrm{C}$ sehingga diperoleh 1,9 gram ekstrak.

\section{Fraksinasi}

Ekstrak etil asetat (0,88 gram) dilarutkan dalam $3 \mathrm{~mL}$ etil asetat. Fraksinasi dilakukan dengan kromatografi kolom cepat Sepacore ${ }^{\circledR}$ (Buchi) yang dilengkapi dengan Fraction Collector. Kolom yang digunakan adalah Glass Column 26/100-044035 yang diisi dengan silica gel 60 for column chromatography, ukuran partikel 0,040 - 0,063 mm, sebanyak 35 gram sebagai fase diam. Elusi dilakukan dengan kombinasi pelarut sebagai berikut: isokratik $n$-heksana:etil asetat (85:15) selama 20 menit, dilanjutkan dengan gradien $n$ heksana:etil asetat (85:15) sampai 100\% etil asetat selama 30 menit, kemudian isokratik $100 \%$ etil asetat selama 7 menit, dan gradien $100 \%$ etil asetat hingga $100 \%$ metanol selama 20 menit. Detektor yang digunakan adalah UV dengan panjang gelombang $270 \mathrm{~nm}$. Pengumpulan fraksi menggunakan mode collect by volume, dengan volume setiap tabung adalah $20 \mathrm{~mL}$. Fraksi yang diperoleh kemudian dikelompokkan berdasarkan pola kromatografi yang dihasilkan.

\section{Uji aktivitas antibakteri}

\section{Pembuatan suspensi bakteri uji}

Suspensi mikroorganisme dibuat setara dengan standar 0,5 McFarland. Standar McFarland ini dibuat dengan mencampur $0,5 \mathrm{~mL}$ barium klorida $0,048 \mathrm{M}$ dan 99,5 $\mathrm{mL}$ asam sulfat $0,18 \mathrm{M}$ kemudian diukur absorbansinya dengan spektrofotometer pada panjang gelombang $625 \mathrm{~nm}$. Rentang absorban dari suspensi standar 0,5 McFarland yang dibuat harus berkisar antara $0,08-0,13$. Jumlah koloni yang terkandung dalam suspensi dapat ditentukan dengan konversi terhadap standar 0,5 McFarland dengan jumlah koloni 1-2 x $10^{8}$ CFU (Colony forming unit)/mL (Wikler dkk., 2009).
Untuk uji dengan metode dilusi suspensi mikroba yang setara dengan standar 0,5 McFarland dipipet sebanyak $1 \mathrm{~mL}$ dan ditambahkan dengan $9 \mathrm{~mL}$ media nutrien broth sehingga diperoleh suspensi mikroba dengan jumlah koloni 1-2 x $10^{7} \mathrm{CFU} / \mathrm{mL}$. Suspensi harus digunakan kurang dari 30 menit setelah pembuatan (Andrews, 2006).

\section{Penyiapan sampel uji}

Ekstrak $(30,0 \mathrm{mg})$ dilarutkan dengan $3 \mathrm{~mL}$ DMSO $2,5 \%$, kemudian proses pelarutan dibantu dengan ultrasonik sampai larut sempurna sehingga didapatkan larutan induk dengan kadar 10.000 ppm. Larutan induk ini kemudian diencerkan secara berseri menjadi konsentrasi 7500, 5000, 1000, 500 dan 200 ppm. Larutan uji ini kemudian digunakan untuk pengujian dengan metode mikrodilusi. Untuk pengujian dengan metode difusi digunakan fraksi dengan konsentrasi 5000 ppm (dibuat dalam metanol).

\section{Uji antibakteri dengan metode mikrodilusi}

Larutan uji yang sudah disiapkan masing - masing diambil sebanyak $50 \mu \mathrm{L}$ kemudian dimasukkan ke dalam 96-well plates yang telah berisi $10 \mu \mathrm{L}$ mikroba uji yang sesuai dan $40 \mu \mathrm{L}$ media sesuai dengan labelnya, sehingga diperoleh jumlah koloni mikroba dalan sumuran sebanyak 1-2 × $10^{6} \mathrm{CFU} / \mathrm{mL}$. Konsentrasi akhir sampel uji di dalam sumuran menjadi setengah dari konsentrasi awal. Selanjutnya, 96-well plates diinkubasi pada $37^{\circ} \mathrm{C}$ selama $24 \mathrm{jam}$. Kemudian ke dalam sumuran ditambahkan $20 \mu \mathrm{L}$ MTT (3-(4,5dimetiltiazol-2-il)-2-5-difenil tetrazolium bromid) yang dilarutkan dalam akuades steril lalu diinkubasi selama 10 - 60 menit pada $37^{\circ} \mathrm{C}$. Apabila terjadi perubahan warna menjadi ungu setelah penambahan MTT menandakan adanya pertumbuhan sel bakteri. Replikasi dilakukan 3 kali, masing-masing secara quadruplo (Ilić dkk., 2015).

Uji aktivitas antibakteri dengan metode difusi agar

Pengujian dengan metode difusi agar dilakukan pada fraksi. Replikasi dilakukan sebanyak 3 kali. Pengujian dilakukan dengan teknis aseptis pada LAFC. Fraksi dilarutkan dalam metanol untuk mendapatkan konsentrasi $5000 \mathrm{ppm}$. Sebanyak $20 \mu \mathrm{L}$ sampel dipipet dan diserapkan ke dalam cakram kertas steril (diameter $6 \mathrm{~cm}$ ). Untuk menghilangkan pengaruh pelarut metanol yang digunakan maka cakram kertas yang sudah berisi larutan uji diangin-anginkan di dekat lampu spiritus selama kurang lebih 1 menit. Cakram kertas tersebut kemudian diletakkan pada cawan petri yang sudah berisi media dan bakteri uji. Siprofloksasin (50 ppm) digunakan sebagai kontrol positif dan metanol 
digunakan sebagai kontrol negatif. Selanjutnya dilakukan inkubasi pada suhu $37^{\circ} \mathrm{C}$ selama 24 jam. Hambatan pertumbuhan bakteri oleh sampel ditunjukkan dengan terbentuknya zona bening di sekitar cakram kertas. Zona bening yang terbentuk diukur dengan jangka sorong sebanyak tiga kali pada tiga bagian yang berbeda, dan dihitung rerata.

\section{Skrining kandungan senyawa}

Ekstrak etil asetat $P$. oxalicum dilarutkan dalam metanol. Sampel kemudian ditotolkan pada plat KLT kemudian dielusi dengan fase gerak kombinasi $n$ heksana : etil asetat $(6: 4)$ untuk skrining senyawa golongan flavonoid, antrakinon dan terpenoid. Untuk skrining senyawa golongan alkaloid digunakan metanol : etil asetat : air $(16,5: 100: 13,5)$, sementara skrining senyawa golongan polifenol menggunakan fase gerak $n$-heksana : etil asetat $(4: 6)$. Visualisasi noda dilakukan dengan pereaksi penampak noda yaitu: uap amonia (flavonoid), larutan KOH 10\% dalam metanol (antrakinon), Dragendorff (alkaloid), anisaldehida$\mathrm{H}_{2} \mathrm{SO}_{4}$ (terpenoid) dan $\mathrm{FeCl}_{3}$ (polifenol) (Wahab dkk., 2010). Pengukuran ${ }^{1} \mathrm{H}$ NMR dilakukan pada instrumen Bruker Avance $500 \mathrm{MHz}$ dengan pelarut $\mathrm{CDCl}_{3}$.

\section{HASIL DAN PEMBAHASAN}

Berdasarkan hasil identifikasi dari daerah $28 \mathrm{~S}$ rRNA isolat jamur endofit yang digunakan pada penelitian ini diidentifikasi sebagai Penicillium oxalicum strain FEC-128. Jamur endofit selanjutnya dikultivasi dalam media cair malt extract selama 6 minggu dan dilanjutkan dengan ekstraksi media dan miselium jamur endofit dengan pelarut etil asetat. Ekstrak yang diperoleh kemudian diuji aktivitas antibakterinya terhadap tiga bakteri patogen yaitu: Staphylococcus aureus ATCC 6538, Bacillus subtilis ATCC 6633 dan Eschericia coli ATCC 2592 dengan metode mikrodilusi. Metode mikrodilusi ini dipilih karena memiliki beberapa kelebihan yaitu, lebih sensitif dari metode difusi, jumlah sampel yang dibutuhkan lebih sedikit serta dapat memberikan hasil semikuantitatif hingga kuantitatif sehingga bisa digunakan untuk penentuan kadar hambat minimum (KHM) secara akurat (Eloff, 1998). Penggunaan pereaksi MTT pada uji mikrodilusi ini bertujuan sebagai penanda adanya bakteri hidup. Pereaksi MTT ini akan direduksi oleh enzim suksinat dehidrogenase yang terdapat dalam mitokondria sel hidup. Hasil reaksi ini akan membentuk kristal formazan berwarna ungu (McCauley dkk., 2013). Timbulnya warna ungu ini kemudian menjadi penanda adanya bakteri hidup.
Berdasarkan hasil uji antibakteri yang disajikan pada Tabel 1 dan Gambar 1 dapat diketahui bahwa ekstrak etil asetat $P$. oxalicum dapat menghambat bakteri pertumbuhan B. subtilis dan E. coli pada KHM sebesar $250 \mu \mathrm{g} / \mathrm{mL}$ sedangkan untuk $S$. aureus KHM $500 \mu \mathrm{g} / \mathrm{mL}$. Berdasarkan nilai KHM ini aktivitas antibakteri pada ekstrak etil asetat $P$. oxalicum termasuk kategori sedang (Marasini dkk., 2015).

Tabel 1. Hasil uji antibakteri ekstrak etil asetat

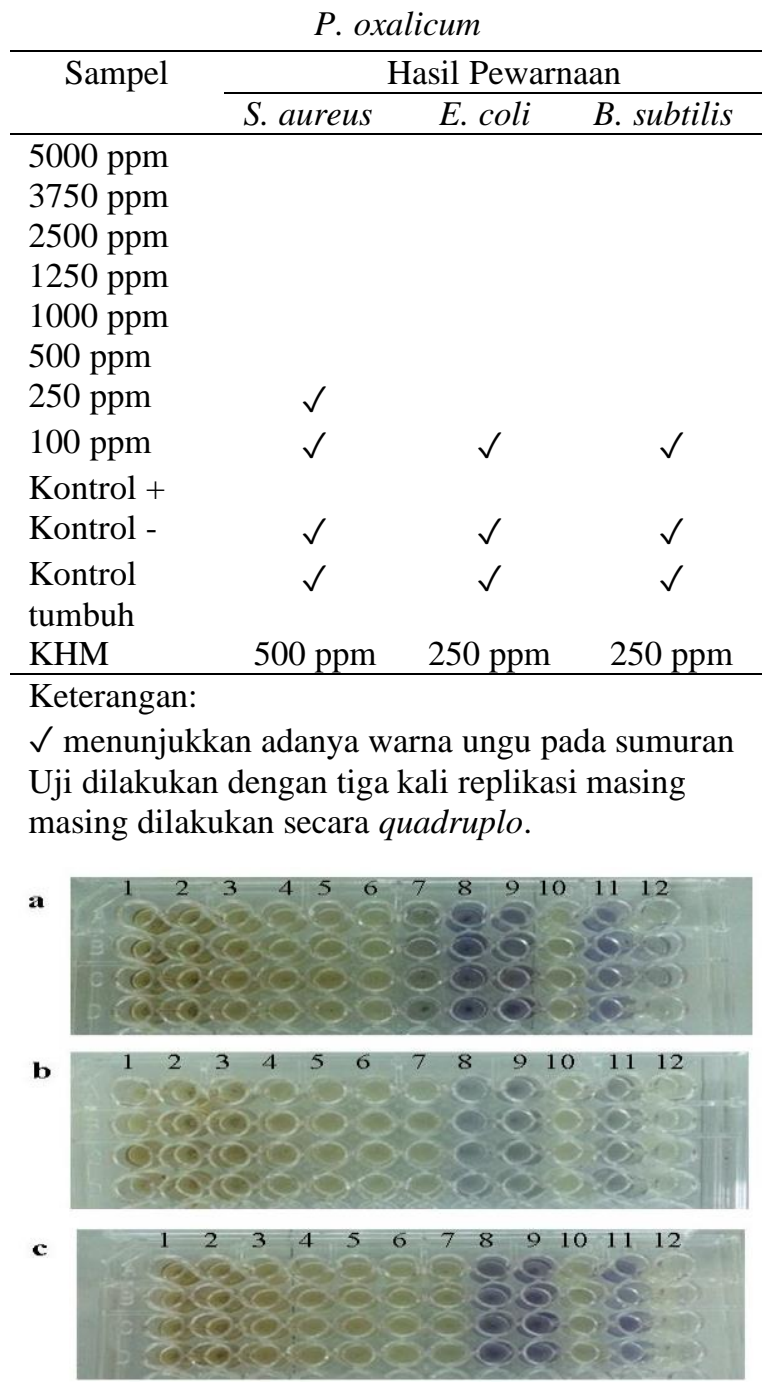

Keterangan: 1: sampel 5000 ppm, 2: 3750 ppm, 3: 2500 ppm, 4: 1250 ppm, 5: 1000 ppm, 6: 500 ppm, 7: 250 ppm, 8: 100 ppm, 9: kontrol pertumbuhan, 10: kontrol media, 11: kontrol negatif (DMSO 2,5\%), 12: Kontrol positif (siprofloksasin $50 \mathrm{ppm}$ ).

Gambar 1. Hasil uji antibakteri dari ekstrak etil asetat P. oxalicum terhadap S. aureus (a), E.coli (b) dan B. subtilis (c)

Selanjutnya hasil fraksinasi ekstrak etil asetat $P$. oxalicum yang diperoleh dengan metode kromatografi 
kolom cepat (Sepacore®) diuji aktivitas antibakterinya dengan metode difusi cakram kertas. Metode ini dipilih karena kelarutan sampel beragam dan tidak semua sampel dapat larut dalam 2,5\% DMSO. Pada metode difusi dengan cakram kertas, sampel dilarutkan dalam metanol kemudian dijerapkan pada cakram kertas. Sisa pelarut metanol pada cakram diuapkan dengan cara diangin-anginkan di dekat lampu spiritus selama 1 menit. Hasil uji antibakteri dari fraksi disajikan pada Tabel 2.

Tabel 2. Hasil uji antibakteri dari fraksi

\begin{tabular}{lccc}
\hline Sample & \multicolumn{3}{c}{ Diameter Zona Hambat (mm)* } \\
\cline { 2 - 4 } & S. aureus & E. coli & B. subtilis \\
\hline F1 & - & - & - \\
F2 & $7,9 \pm 0,39$ & $8,5 \pm 0,62$ & $9,3 \pm 0,10$ \\
F3 & $7,6 \pm 0,48$ & $9,3 \pm 0,14$ & $8,5 \pm 0,63$ \\
F4 & $8,2 \pm 0,92$ & $9,2 \pm 0,06$ & $10,2 \pm 0,16$ \\
F5 & $8,9 \pm 0,66$ & - & $8,3 \pm 0,19$ \\
F6 & - & $8,3 \pm 0,11$ & $9,7 \pm 0,58$ \\
F7 & $8,3 \pm 0,01$ & $8,8 \pm 0,35$ & $9,6 \pm 0,54$ \\
F8 & $7,9 \pm 0,41$ & $8,2 \pm 0,17$ & $9,0 \pm 0,43$ \\
F9 & $7,3 \pm 0,83$ & - & - \\
Kontrol + & $28,9 \pm 1,4$ & $22,5 \pm 0,80$ & $34,9 \pm 0,25$ \\
Kontrol - & - & \multicolumn{3}{c}{-} \\
Keterangan: & \multicolumn{3}{c}{ * rerata zona hambat \pm SD dari tiga replikasi } \\
-: Tidak ada zona hambat yang teramati
\end{tabular}

Hasil uji antibakteri dari kesembilan fraksi ekstrak etil asetat $P$. oxalicum menunjukkan bahwa, fraksi 2 4 dan fraksi 6 - 8 dapat menghambat pertumbuhan $E$. coli dengan zona hambat berkisar antara 8,2 - 9,3 mm. Fraksi 2 - 8 memberikan zona hambat berkisar antara 8,3 - 10,2 mm terhadap bakteri uji B. subtillis, dan fraksi 2 5 dan 7 - 9 memberikan zona hambat berkisar antara 7,3 - 8,9 mm terhadap bakteri S. aureus. Hasil tersebut menunjukkan bahwa fraksi memberikan aktifitas penghambatan yang sedang terhadap ketiga bakteri uji.

Pada ekstrak etil asetat $P$. oxalicum juga dilakukan skrining kandungan senyawa kimia dengan metode KLT hasil yang diperoleh disajikan pada Tabel 3 dan Gambar 2 yang menunjukkan bahwa ekstrak etil asetat $P$. oxalicum mengandung senyawa golongan terpenoid dan polifenol. Hasil tersebut juga dikuatkan dengan hasil pengukuran spektroskopi ${ }^{1} \mathrm{H}$ NMR (Gambar 3) yang menunjukkan adanya serapan pada 6,0 - 8,0 ppm yang spesifik menunjukkan adanya gugus aromatik/fenol, juga serapan 0,5 - 4,0 ppm yang kemungkinan berasal dari gugus metil dan metilena pada senyawa terpenoid (Field dkk., 2013).

Tabel 3. Hasil skrining golongan senyawa

\begin{tabular}{lccc}
\hline $\begin{array}{l}\text { Golongan } \\
\text { senyawa }\end{array}$ & $\begin{array}{c}\text { Penampak } \\
\text { noda }\end{array}$ & Hasil & $\begin{array}{c}\text { Warna } \\
\text { noda }\end{array}$ \\
\hline Flavonoid & Uap & - & - \\
Alkaloid & $\begin{array}{c}\text { Damoniak } \\
\text { Dragendorff }\end{array}$ & - & - \\
Antrakinon & KOH dalam & - & - \\
& $10 \%$ MeOH & & Merah- \\
Terpenoid & $\begin{array}{c}\text { Anisaldehid } \\
\text { a- } \mathrm{H}_{2} \mathrm{SO}_{4}\end{array}$ & + & \\
& $\mathrm{FeCl}_{3}$ & + & Hitam \\
Polifenol & & & \\
\hline
\end{tabular}

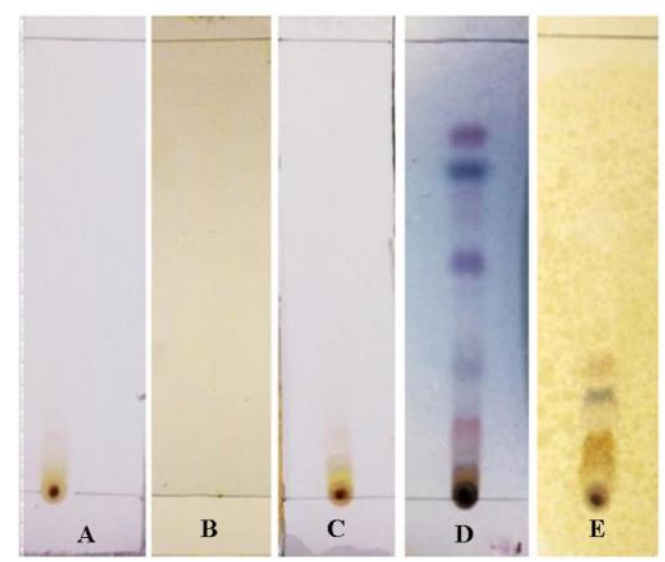

Gambar 2. KLT skrining golongan senyawa flavonoid (A), alkaloid (B), antrakinon (C), terpenoid (D) dan polifenol (E)

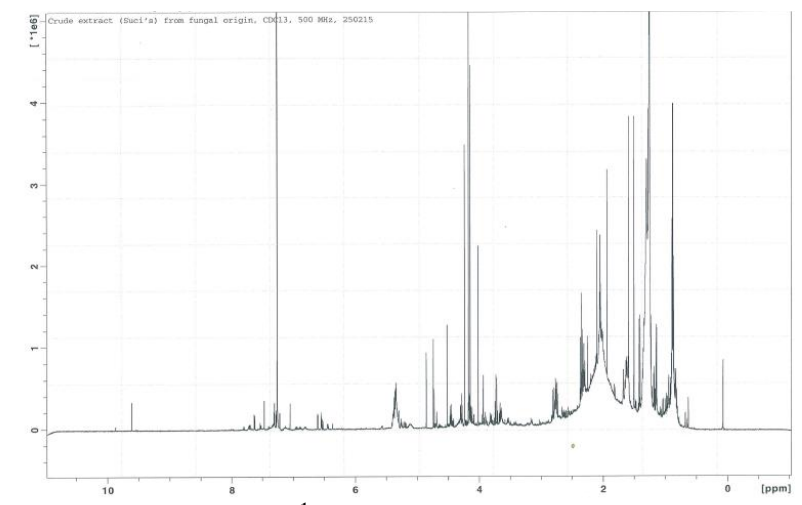

Gambar 3. Spektrum ${ }^{1} \mathrm{H}$ NMR ekstrak etil asetat $P$. oxalicum 
Senyawa golongan terpenoid diketahui memiliki aktivitas antibakteri terhadap bakteri Gram positif maupun Gram negatif, sebagai contoh eugenol dapat merusak membran sel dari bakteri tersebut. Senyawa polifenol juga dilaporkan sebagai antibakteri, misalnya resveratrol dapat menghambat Campylobacter jejuni, Arcobacter butzleri dan Arcobacter cryaerophilus. Senyawa fenolik lainnya misalnya baicalein dapat menghambat $S$. aureus, E. coli, B. subtilis dan $P$. aeruginosa. Baicalein juga diketahui memiliki efek sinergisme bersama dengan antibiotik $\beta$-laktam (Khameneh dkk., 2019).

\section{KESIMPULAN}

Ekstrak etil asetat dan fraksi $P$. oxalicum menunjukkan aktivitas antibakteri terhadap S. aureus, B. subtilis dan $E$ coli. Aktivitas antibakteri tersebut kemungkinan disebabkan adanya senyawa terpenoid dan fenolik pada $P$. oxalicum.

\section{DAFTAR PUSTAKA}

Andrews, J. M. (2006). Determination of Minimum Inhibitory Concentration. Journal of Antimicrobial Chemotherapy; 48; 5-16.

Blunt, J. W., Carroll, A. R., Copp, B. R., Davis, R. A., Keyzers, R. A. \& Prinsep, M. R. (2018). Marine Natural Products. Natural Product Reports; 35; 8-53.

Cafieri, F., Fattorusso, E., Mangoni, A. \& TaglialatelaScafati, O. (1995). Longamide and 3,7dimethylisoguanine, Two Novel Alkaloids from the Marine Sponge Agelas longissima. Tetrahedron letter; 36; 7893-7896.

Eloff, J. N. (1998). A Sensitive and Quick Microplate Method to Determine the Minimal Inhibitory Concentration of Plant Extracts for Bacteria. Planta Medica; 64; 711-713.

Field, L. D., Sternhell, S. \& Kalman, J. R. (2013) Organic Structures from Spectra (5th ed.). Chichester: John Wiley \& Sons., Ltd.

Ilić, M. D., Jovanović, V. P. S., Mitić, V. D., Jovanović, O. P., Mihajilov-Krstev, T. M., Marković, M. S. \& Stojanović, G. S. (2015). Comparison of Chemical Composition and Biological Activities of Seseli rigidum Fruit Essential Oils from Serbia. Open Chemistry; 13; 42-51

Kementerian Kesehatan (Kemenkes) RI. (2019). Hasil Utama Riskesdas 2018 by Kemenkes RI. https://kesmas.kemkes.go.id. Accessed: $21 \mathrm{Mei}$ 2020.

Kementerian Kesehatan (Kemenkes) RI. (2016). Data dan Informasi: Profil Kesehatan Indonesia 2016. https://pusdatin.kemkes.go.id/article/view/17092 000001/profil-kesehatan-indonesia-2016.html. Accessed: 10 Maret 2020.

Khameneh, B., Iranshahy, M., Soheili, V. \& Bazzaz, B. S. F. (2019). Review on Plant Antimicrobials: a Mechanistic Viewpoint. Antimicrobial Resistance and Infection Control; 8; 118.

McCauley, J., Zivanovic, A. \& Skropeta, D. (2013). Bioassays for Anticancer Activities. In: Roessner U., Dias D. (eds) Methods in Molecular Biology (Methods and Protocols). Totowa: Humana Press.

Marasini, B. P., Baral, P., Aryal P., Ghimire, K. R., Neupane, S., Dahal, N., Singh, A., Ghimire, L. \& Shresta, K. (2015). Evaluation of Antibacterial Activity of Some Traditionally Used Medicinal Plants Against Human Pathogenic Bacteria. BioMed Research International; 2015; 6.

Umeyama, A., Ito, S., Yuasa, E., Arihara, S. \& Yamada, T. (1998). A New Bromopyrrole Alkaloid and the Optical Resolution of the Racemate from the Marine Sponge Homaxinella sp. Journal of Natural Products; 61; 1433-1434

Schmidt, E. W., Obraztsova, A. Y., Davidson, S. K., Faulkner, D. J. \& Haygood M. G. (2000) Identification of the Antifungal PeptideContaining Symbiont of the Marine Sponge Theonella swinhoei as a Novel $\delta$ Proteobacterium, "Candidatus Entotheonella palauensis". Marine Biology; 136; 969-977.

Suciati, Alrosyidi, A. F. \& Sugijanto, N. E. (2014). Isolasi dan Skrining Antimikroba Jamur Endofit dari Beberapa Spong Indonesia. Planta Husada; 2; 40-43.

Wahab, O. M., Ayodele, A. E. \& Moody, J. O. (2010). TLC Phytochemical Screening in Some Nigerian Loranthaceae. Journal of Pharmacognosy and Phytotherapy; 2; 64-70.

Wikler, M. A., Cockerill, F. R. \& Bush, K. D. (2009). Performance Standard for Antimicrobial Disk Susceptibility Test; Approved Standard (10th ed.). Pennsylvania: Clinical and Laboratory Standards Institute. 